\title{
THE PROGRAM OF THE PSYCHOLOGICAL TRAINING ON CORRECTION OF SELF-REGULATION MECHANISMS OF ADOLESCENT BEHAVIOR
}

У статті актуалізовано проблему становлення психологічних механізмів саморегуляції поведінки підлітків; розширено теоретичні та методичні уявлення про особливості розвитку й сутність даного феномену. Поняття «психологічні механізми саморегулячії поведінки особистості підлітка» розуміється як структурне утворення самосвідомості, що інтегрує в собі здатність визначати чіннісні орієнтації, здібність досягати мети адекватно внутрішнім потенціалам, можливість самоконтролю, прагнення до успіху / самореалізації, потребу просоціального самоствердження та визнання. Презентовано провідні механізми саморегуляції поведінки підлітків. Такими механізмами є: рівень домагань, ціннісні орієнтації, локус контролю, мотивація схвалення, потреби в досягненні успіху, визнанні, самоствердженні. Передбачено, що підвищення рівня організованості психологічних механізмів саморегуляції особистості підлітка зумовлюється провідним психологічним механізмом даного віку самосвідомістю, функціональне перетворення якої здійснюється способами самосприйняття, рефлексії, самовизначення, самопізнання. Визначено підходи, шляхи, методи і прийоми становлення механізмів саморегуляції поведінки підлітків. Представлено програму психологічного тренінгу з корекції механізмів саморегуляції поведінки підлітків. Метою програми є нівелювання малоконтрольованих дій і вчинків, пов'я заних з особистісною ссрерою, та вправляння підлітків у конструктивних способах поведінки; активізація процесів самоспостереження, самоаналізу, самопізнання; формування умінь та навичок особистісноі саморегуляції. Корекційно-профрілактичними заходами стали методи моделювання ситуацій, зворотного зв'язку, проєктивного малювання, ігровий, пояснювальної психотерапії. Психологічний тренінг містить три блоки: спочатку вправляння і корекція психологічних механізмів молодої особистості відповідно до визначених особливостей ціннісних орієнтацій і рівня домагань, потім залежно від локусу контролю, потреб у досягненні успіху та схваленні, зрештою, згідно із прагненнями підлітка до визнання та самоствердження. У підсумку зазначено, що психологічний тренінг, який має тісні взаємозв'язки з навчанням, зумовлює виникнення ланцюга особистісних відкриттів, має свою логіку, цільову спрямованість, зорієнтований на зміни визначених механізмів саморегуляції.

Ключові слова: особистісна саморегуляція, саморегуляція поведінки, механізми саморе- гуляції поведінки підлітків, корекція, арт-терапія, психологічний тренінг.

The article actualises the problem of formation of psychological self-regulation mechanisms of teenagers behavior; theoretical and methodical ideas about the peculiarities of development and the essence of this phenomenon are expanded. The concept of psychological self-regulation mechanisms of adolescent personality is understood as a structural formation of self-awareness that integrates the ability to determine value orientations, the ability to achieve goals adequately to internal potentials, self-control, desire for success (self-realization), the need of prosocial self-affirmation and recognition. Leading self-regulation mechanisms of adolescent behavior are presented. Such mechanisms are: the level of acheivements, value orientations, locus of control, motivation for approval, the need for success, recognition, self-affirmation. It is assumed that the increase of the level of organization of psychological self-regulation mechanisms of adolescent personality is caused by the leading psychological mechanism of this age - self-awareness, the functional transformation of which is carried out by self-perception, reflection, self-determination, self-understanding. Approaches, ways, methods and procedures of formation of self-regulation mechanisms of teenagers behavior are defined. The program of psychological training on correction of self-regulation mechanisms of adolescent behavior is presented. The purpose of the program is to eliminate uncontrolled actions and deeds related to the personal sphere and to correct adolescents in constructive ways of their behavior; activation of the processes of self-observation, self-analysis, self-understanding; formation of skills and abilities of personal self-regulation. Methods of modeling situations, feedback, projective drawing, game, explanatory psychotherapy were used as corrective and preventive measures. Psychological training includes three blocks, as follows: first, exercise and correction of psychological mechanisms of the growing personality in accordance with certain characteristics of values and level of achievements, then depending on the locus of control, the need for success and approval and, finally, in accordance with the adolescent's desire of recognition and self-affirmation. As a result, it is noted that the psychological training, having close links with learning, determines the emergence of a chain of personal discoveries, has its own logic, focus and is aimed at the change of certain self-regulation mechanisms.

Key words: personal self-regulation, behavior self-regulation, self-regulation mechanisms of adolescent behavior, correction, art therapy, psychological training.
Постановка проблеми. Пріоритетною ознакою сучасного етапу розвитку психології $€$ гостра потреба пошуку тих сутнісних характеристик особистості, які б сприяли конструктивному розв'язанню численних проблем у всіх формах її активності. Фундаментальною вцьомуконтекстівиступаєсаморегуляція. Особистісна саморегуляція постає індикатором успішності, засобом саморозвитку, самореалізації і досягнення суб'єктом поставленої мети.

Сензитивним для становлення саморегуляції поведінки особистості виступає підліт- 
ковий вік, який характеризується інтенсивним розвитком інтелектуальних здібностей, поглибленням особистісної рефлексії, прагненням до саморозвитку, самоствердженням своєї індивідуальності, осмисленням домагання соціального визнання. Саме в цей період відбувається усвідомлення підлітком своєї індивідуальності, змінюється його ставлення до навколишнього світу, до себе, до інших людей. Водночас іншими стають і вимоги суспільства до нього. Отже, молодій людині необхідно вміти узгоджувати свої прагнення з очікуванням оточення, адаптуватися до соціальних норм та правил поведінки, у зв'язку із чим акцент у вихованні підлітків треба ставити на особливостях формування механізмів саморегуляції поведінки.

Аналіз останніх досліджень і публікацій. Проблема саморегуляції поведінки особистості досліджується і постійно активізується вченими різних галузей психологічної науки. У теорії людино-центрованого підходу саморегуляція представлена концепцією функціонуючої особистості. Інтегральним механізмом саморегуляції поведінки виступає Я-концепція, як важливий компонент структури особистості. Згідно з поглядами К. Роджерса [8], кожній людині притаманна здатність до особистісного вдосконалення, самоактуалізації. Прагнення до здорового розвитку визначається як сила, яка переважає, мотивує людину, скеровує в певне русло, оскільки кожен індивід володіє всебічними внутрішніми ресурсами самосвідомості та саморегулюючої поведінки. Гуманістична психологія доцільним уважає цілісне вивчення особистості, наголошує на довільності поведінки, ролі справжніх духовних цінностей і переконань у її суспільному становленні. А. Маслоу [6] розглядає особистість як принципово вільну і відповідальну за рішення, який спосіб життя вибрати, яким є їі потенціал і яким чином вона буде актуалізовувати цей ресурс. Самоактуалізовані індивіди наполегливо йдуть до поставленої цілі, важливим компонентом у цьому довготривалому процесі $є$ воля людини. У соціально-когнітивній теорії А. Бандури [1] саморегуляція розглядається як одна з найважливіших характеристик людини, яка впливає на її поведінку.

Сутність процесу саморегуляції молодої особистості, згідно з поглядами М.Й. Боришевського [2], Ю.А. Миславського [7], розглядаємо, по-перше, у її здатності усвідомлювати і проявляти себе суб'єктом власної активності, займати позицію суб'єкта у взаємодії з іншими, а також тлумачимо як єдність соціальних та психологічних (рефлексивні, мотиваційні, вольові) проявів свідомості й самосвідомості індивіда.

На наш погляд, саморегуляція особистості і є цим засобом реалізації спонук і потен- цій індивіда, саме вона слугує специфічним коректором означених потреб і цілей в умовах мінливих зовнішніх і внутрішніх чинників середовища чи ситуації.

Постановка завдання. Метою статті $€$ презентація й обґрунтування програми психологічного тренінгу корекції механізмів саморегуляції поведінки підлітків.

Виклад основного матеріалу. Важливим завданням практичної психології $€$ надання допомоги людині в досягненні гармонії ії̈ внутрішнього світу, у розвитку здатності до самореалізації. Особливо актуальним це завдання виступає в підлітковому віці, у період загострення внутрішніх суперечностей особистості дитини, нестійкості її прагнень, переживань, емоційних станів, характеру і поведінки. Саме в цей період розвиток уявлень про себе і самооцінка стають найбільш актуальними, виступають головними віковими новоутвореннями [3]. Щоб новоутворення розвивалися, необхідно створити відповідні умови, зокрема «зону найближчого розвитку», оскільки вони $є$ результатом власного досвіду дитини, отриманого внаслідок включення її в різні види діяльності, насамперед у провідну для підліткового віку спілкування. Але, як зазначав А. Маслоу [6], вибір методів, що сприяють досягненню мети, часто викликає в індивіда великі труднощі. Адже підлітки не мають належних навичок, досвіду, волі, які необхідні для саморегуляції поведінки, для самоствердження особистості соціально виправданими засобами.

Одним із важливих рішень цього завдання єрозвитокмеханізмівсаморегуляціїповедінки в підлітковий період. Психологічні механізми саморегуляції закріплюються у психологічній організації особистості як функціональні способи її перетворень, у результаті яких з'являються різні психологічні новоутворення, підвищується або знижується рівень особистісної системи, змінюється режим її функціонування. Провідними психологічними механізмами процесу саморегуляції поведінки в підлітковому віці є: рівень домагань, ціннісні орієнтації, локус контролю, мотивація схвалення, потреби в досягненні успіху, визнанні та самоствердженні.

Сучасний етап розвитку психології характеризується великим арсеналом методичного інструментарію, серед якого чільне місце посідають методи активного психологічного впливу на особистість [4; 10]. До таких методів відносять психологічний тренінг, який охоплює систему психологічний вправ, психологічних та ділових ігор, якіі застосовують 3 метою розвитку вольової сфери окремих психічних процесів та самозростання й саморозвитку індивіда як удосконалення особистісної саморегуляції. Т.В. Сінєльнікова [9] вважає, що поняття тренінгу та навчання тісно 
взаємопов'язані. Навчання може бути елементом тренінгу, тренінг може виступати елементом навчання. Із цього випливає, що тренінг обов'язково є педагогічною технологією.

Об'єктом тренінгових процедур, за твердженням В.О. Лефтерова [5], передусім виступає людина зі своїм неповторним внутрішнім світом, індивідуальними особливостями, системою відносин і цінностей. Самоаналіз, який відбувається в людини під час тренінгу, майже завжди стає поштовхом до особистісних змін, перетворення психічних компонентів її життя і діяльності.

Підґрунтям для розроблення програми психологічного тренінгу корекції механізмів саморегуляції поведінки підлітків слугували визначені нами такі моменти:

- уміння підлітка прогнозувати та передбачати можливі наслідки і реакції як із боку соціального оточення, так і самого себе;

- опанування на даному віковому етапі навичок рефлексивних очікувань наслідків певних варіантів поведінки;

- здатність у перехідному віці планувати подальшу діяльність щодо реалізації ціннісних орієнтацій;

- актуалізація в підлітків потреби до досягнення успіху, реалізація в них умінь досягати задуманого результату, можливість правильно вибирати мету, здійснювати пошуки шляхів її досягнення.

Метою програми є нівелювання малоконтрольованих дій та вчинків, пов'язаних з особистісною сферою, вправляння підлітків у конструктивних способах поведінки; активізація процесів самоспостереження, самоаналізу, самопізнання; формування вмінь та навичок особистісної саморегуляції.

Завдання програми:

- самосприйняття власного реального / реалістичного «я», проєктування рефлексивних очікувань референтних осіб стосовно нормативного «Я», антиципація власних дій у просторі різних проблемних / критичних)ситуацій;

- рефлексивний аналіз егоцентричного й децентричного «Я», переорієнтація з досягнення результату на спосіб виконання завдання, актуалізація інтернального локусу контролю, усвідомлення особистістю підлітка власних якостей / самоцінностей;

- актуалізація потреби досягнення успіху, стимулювання мотиву «бути не гірше за інших», осмислення проблем, пов'язаних із комунікативними контактами у спільності ровесників (клас, вулиця), визначення рольової позиції, престижу і статусу у групах однолітків;

- усвідомлення пріоритету просоціальних цінностей у життєвому просторі, усвідомлення себе суб'єктом саморозвитку, який відповідає за особисті рішення та вчинки, ухвалення довільного рішення в конкретній ситуації, планування свого життя.
Програма розрахована на тренінгові заняття тривалістю 1,5 години (90 хвилин), які проводяться раз на тиждень. Кількість учасників в одній групі - 12-16 осіб, саме в таких групах позитивні ефекти занять можуть проявлятись найбільш виражено. У колективній та індивідуальній роботі з підлітками використано способи розвитку механізмів саморегуляції поведінки (пояснювальної психотерапії, позитивного і негативного підкріплення, моделювання ситуацій, зворотного зв'язку, ігровий), які підвищують ефективність тренінгових занять з учнями підліткового віку.

Програму психологічного тренінгу ми поділили на три блоки: спочатку вправляння і корекція психологічних механізмів особистості підлітка відповідно до визначених особливостяей ціннісних орієнтацій і рівня домагань, потім залежно від локусу контролю, потреб у досягненні успіху та схваленні, зрештою, згідноі з прагненнями підлітка до визнання та самоствердження. Є суттєві підстави для виділення окремих блоків зі специфічними цілями та завданнями, що у своєму поєднанні мають бути спрямовані на корекцію та пізнання учнями власних особистісних властивостей і якостей, важливих для особистісної саморегуляції поведінки підлітків.

Перший блок - це збагачення ціннісного досвіду дитини як здатності орієнтуватися у вічних і перехідних вартостях, смислах, принципах та нормах життя. Цей блок містить відповідні бесіди, аналіз конкретних життєвих випадків, приклади з художньої літератури й історії. Загальновизнано, що оцінка є ефективним засобом впливу на розвиток підлітків загалом, як важливий зовнішній регулятор поведінки вона згодом перетворюється на внутрішній механізм саморегуляції. Завдяки оцінним судженням молода особистість поступово починає усвідомлювати, що добре, а що погано, тобто засвоює правила та норми поведінки. Оцінні ставлення виступають як застереження від конфліктів з оточенням, а в повсякденному житті дають можливість підліткам засвоювати суспільні нормативи. Адже особистість у підлітковому віці надає високої «ціни», значущості думці та позиціям своїх ровесників або старших за віком представників юнацького віку. Загалом це сприяє формуванню навичок самоаналізу в підлітків, стимуляції в них інтересу як до власного внутрішнього світу, так і до внутрішнього світу інших. Окрім цього, рекомендовано застосовувати низку психотехнік, як-от: «Пресконференція», «Мої ідеали», «Наші почуття і емоції», методичні прийоми яких спонукають підлітків до відтворення людських якостей, які їх не влаштовують у життєвому просторі. Наприкінці пропонується груповий диспут, з акцентом на питання: «Чи потрібно негативні почуття приховувати і в жодному разі не вира- 
жати?». Також досить ефективні в цьому блоці арт-терапевтичні вправи, як-от намалювати себе тричі: реальне «Я» - яким я зараз себе уявляю; соціальне «Я» - яким мене бачать інші; ідеальне «Я» - яким би я хотів бути, звернутися до батьків, друзів із проханням оцінити їхні портрети, узагальнити ці відомості та промотивувати: «Який із цих портретів сподобався більше? Чому?». Після чого порівняти, чи збігається соціальне оцінне ставлення з їхнім власним ставленням до себе. На завершення цього етапу виконуються техніки «Вибір», «Моральні й індивідуальні цінності» для визначення життєвих цінностей-цілей, тому що деяким підліткам буває дуже важко самостійно зробити такий вибір, а для цього треба навчитися користуватися всіма своїми найкращими сторонами, що допоможе реалізувати цінності-засоби для досягнення цінностей-цілей. Найбільш придатною для підлітків під час визначення власних життєвих цілей $є$ уявна ситуація. Пропонується уявити своє майбутнє життя - як би вони хотіли, щоб воно склалося; з тими «дорогами», якими вони хотіли б пройти; з тими «вершинами», на які хотіли б зійти. Після чого письмово зафіксувати свої мрії.

Наступний блок - це вправляння і корекція психологічних механізмів особистості підлітків, для яких провідним чинником, що призводить до порушень саморегуляції поведінки визначається мотиваційний, залежно від локусу контролю, потреб у досягненні успіху та схваленні Так, завданням перших занять $€$ орієнтування підлітків на інтернальний локус контролю. Із цією метою пропонується діагностична методика визначення когнітивної орієнтації (локус контролю) Дж. Роттера для виявлення спрямованості особистості підлітка на зовнішні або внутрішні стимули. Групова дискусія на тему: «Як ми вміємо виправдовуватися перед самим собою", а також техніки «Мій внутрішній стан», «Упевнена, невпевнена, груба поведінка», в основі яких покладено формування в підлітків навичок самодостатньої, тобто врегульованої поведінки. Оскільки локус контролю як інтегративна риса індивіда пов'язаний передусім із Я-концепцією особистості, то ми звертали увагу саме на цей важливий момент.

Наступний етап цього блоку спрямований для підсилення мотиву досягнення успіхів у підлітків. 3 метою виявлення рівня розвитку мотивації досягнення рекомендується провести діагностичну методику «Шкала оцінки потреби в досягненні» Ю.М. Орлова. За допомогою методики сформувати в підлітків упевненість у тому, що незадоволеність досягнутим, прагнення до поліпшення особистих результатів, наполегливість у досягненні поставленої мети допомагають успіху в житті.
Основними шляхами тренінгової роботи з підлітками є:

- стимулювання мотиву «бути не гірше за інших»;

- розвиток активності, досягнення успіху, планування свого життя.

У процесі роботи з підлітками ми взяли до уваги той факт, що підлітки надто чутливі до оцінки результатів власної діяльності, хворобливо бояться й уникають невдачі. Для цього рекомендується цикл занять, метою яких $€$ допомога підліткам розібратися у власних прагненнях, максимально реалізувати свої можливості, а тим самим навчитись урегульовувати свої дії та вчинки відповідно до поставленої мети, як-от: зміна системи оцінок, деталізація значущих образів, техніки «Визначення пріоритетів», «Атлет», арт-терапевтична вправа «Безпечний простір» тощо. А також мінілекції, де аргументувалося, що важливою нині $\epsilon$ цінність - досягнення успіху, значущість суб'єктивного відчуття власної влади над життям, над своєю долею. Для реалізації цієї мети необхідно цілеспрямовано планувати і прогнозувати свої дії та вчинки. Застосування прийому планування. Підліткам дається завдання - уявити своє майбутнє життя як «художній фільм», у якому вони грають головну роль. Отже, підліток сам - і сценарист, і режисер, і директор картини. Він може вирішувати, про що буде фільм, йому необхідно вибирати персонажів, де будуть відбуватися події. У першій серії занять другого етапу підлітки визначають, у якому часовому вимірі вони працюють. Після чого складається список необхідних якостей для досягнення цілей-засобів, які вони мають. У кінці заняття підбивається підсумок, що кожний для себе повинен вирішити, наскільки він прагне до успіху, ким хоче бути в житті - переможцем чи переможеним. Щоб максимально наблизити ці тези до кожного з підлітків, ми запропонували пригадати 3-5 випадків із свого життя, де була реалізована мотивація досягнення успіху. У другій серії занять цього етапу розроблялась стратегія досягнення успіху. Підлітки моделюють особистісний простір тих, хто вже досягнув у житті успіхів. На заключному занятті підлітки розмірковують над запитанням: «Якщо і надалі буду жити, як тепер, робити все так, як роблю зараз, - чи досягну я того, до чого прагну?». Якщо ж домінує відповідь «Ні» або «Тільки частково», то треба поміркувати над тим, як удосконалювати себе. Рекомендовано вправи різного рівня («Дихання», «Контроль голосу та жестів», «Приємні спогади», «Маяк», «Виконання ролі», «Настрій»).

Серед підтверджених у нашому дослідженні $€$ також гіпотеза про опосередкування саморегуляції поведінки механізмом схвалення. Даний механізм полягає в позитив- 
ній оцінці, схваленні вже здійснених учинків, підтримці та спонуканні підлітків до регуляції поведінки. У процесі дослідження ми виявили, що одним із моментів, що заважає саморегуляції поведінки, є те, що підлітки, яким властивий низький рівень потреби у схваленні, хворобливо реагують на критику. Підліткам пропонується діагностична методика «Шкала мотивації схвалення (Кроун-Марлоу), щоб оцінити рівень розвитку мотивації схвалення у підлітків, із цією метою проводиться мінілекція «Чому я заслуговую на повагу?», а також арт-терапевтична вправа: учні малювали сонце, у центрі сонячного кола писали своє ім'я. Потім уздовж промінців писали все хороше, що вони про себе знають. Водночас давалася настанова на те, щоб було якомога більше таких промінців. Формування глибших уявлень про власне «я» пов'язане з технікою «Чим я привабливий». За допомогою 5-6 слів необхідно описати свою зовнішність, зокрема назвати те, що робить їх привабливими. Після цього вся група таким же чином характеризувала одного з учнів. Кожна індивідуальність повинна бути переконана, що вона має досить приємну зовнішність і такі особистісні риси, які можуть сподобатися іншим.

На цьому жетапі були підібрані гумористичні історії про учнів, які боялися критики. Використання техніки «Коло знайомств» надає можливість кожному учаснику групи показати себе групі, виразити свою індивідуальність у гумористичній формі за допомогою пантоміми.

Третій блок програми тренінгу спрямований на вправляння і корекцію просоціальних механізмів саморегуляції поведінки - самоствердження та визнання. Мета першої серії занять - допомогти підліткам побачити загострені риси власної особистості, які слугували причиною власних конфліктів, труднощів у спілкуванні. Адже спілкування несе як позитивні, так і негативні емоції. А переживання щодо спілкування з однолітками є досить значущими в їхньому життєіснуванні. У тренінговій програмі ми вдалися до використання ефективних форм роботи, що пов'язані з якісним аналізом особистісних характеристик і ситуацій поведінкових реакцій вигаданих «героїв» однолітків в окремих «психологічних портретах» чи «сюжетах» з їхнього життя.

3 метою формування вмінь аналізувати себе й інших у ситуаціях неадекватної поведінки (коли нівелюються саморегулятивні аспекти) і «егоцентричного» самостверджувального спілкування, рекомендується проводити техніку «Скарбничка-образ», після чого бесіда за темою «Мої зовнішні і внутрішні почуття». Для полегшення спілкування необхідно свідомо (довільно) контролювати свої зовнішні та внутрішні почуття. Для цього вправляли підлітків у різних повідомленнях. Пропонуються «жар- тівливі» змагання, опосередкування, орієнтація на спосіб виконання, аналіз переживань із власного досвіду, психогімнастика «Поплавок» із метою навчити підлітків цілеспрямовано регулювати свій внутрішній стан, не піддаючись ні настрою, ні обставинам, що склались.

Наступні три заняття були спрямовані на розвиток потреби у визнанні. Рекомендується за допомогою рефлексивного аналізу визначати атмосферу міжособистісних стосунків, а такожтехніки «Станьте в коло». Використання даного прийому допоможе підліткам зрозуміти, яке значення можуть мати взаєморозуміння, уміння діяти узгоджено, щоб урегульовувати, співвідносити свої дії з діями товаришів. Важливим аспектом цього блоку тренінгової програми $є$ розвиток навичок самоаналізу як механізму самовдосконалення. Для цього пропонується використовувати в роботі з підлітками такі техніки, вправи і прийоми, процес проведення яких підсилював розгортання регулятивного процесу Я-концепції. Мотивація до самоаналізу здійснювалася в інструкціях, які надаються заздалегідь в усній і розгорнутій формі. Більшість психотехнік сприяли релаксації, внутрішньому діалогу - вільному розмірковуванню про свої особисті проблеми.

Невід'ємною складовою частиною виховної роботи є діагностика індивідуально-психологічних особливостей підлітків. Тому підліткам пропонується інформативний спосіб вивчення тривожності, агресивності, фрустрації, ригідності учнів. Зазначені характеристики виконують регулюючу функцію щодо процесу самоствердження, деяким чином зумовлюють вибір способів та засобів його здійснення. Так, техніка «Мій всесвіт» виступає як тренувальна і спонукає до відтворення власних інтересів, можливостей та здібностей. Підліткам необхідно в центрі альбомного аркуша намалювати коло - сонце. У його центрі написати велику букву «Я». Потім від «Я» - центру свого всесвіту накреслить лінії - промінці до інших зірок і планет. У техніці «Я-реальне, Я-ідеальне» підліткам необхідно виписати у стовпчик із заданого списку прикметників слова, які максимально точно характеризують кожного з них, прорангувати їх, відповісти на запитання: «які якості Вам у собі подобаються, які ні? (Підкреслить кольоровими олівцями). Скільки тих та інших? Чого хотіли б набути, а від чого відмовитися?», «Які якості допомагають управляти поведінкою?», «Які якості заважають саморегуляції поведінки?». У цих психологічних портретах особлива увага концентрується на вольових якостях особистості (самодисципліна, контроль поведінки, цілеспрямованість, уміння володіти собою). Найбільш простим і ефективним способом розслаблення є глибоке, ритмічне дихання. Наприклад, робити видих удвічі довшим, чим вдих: у разі сильної напруги зро- 
бити глибокий вдих та затримати дихання на 20-30 секунд. Метою технік «Аукціон ідей», «Стій! Подумай! Дій!» $€$ навчити підлітків визначати способи конструктивної / саморегулятивної поведінки залежно від перебігу різних емоційних станів. Пропонована гра «Чарівний базар» спрямована на актуалізацію в підлітків уваги до власних індивідуально-психологічних якостей. Метою техніки «Визначення пріоритетів» $€$ навчання способів самоконтролю, створення умов для свідомого прийняття підлітками відповідальності за розвиток свого «Я».

Висновки. Отже, вищесказане дозволяє зробити висновок, що психологічний тренінг як особистісний простір являє собою універсальну систему цілеспрямованого психологічного тренування підлітків відповідно до потреб внутрішнього світу особистості.

Психологічний тренінг, який має тісні взаємозв'язки з навчанням, зумовлює виникнення ланцюга особистісних відкриттів і передбачає включення мотиваційної, вольової та рефлексивної сфер. Тренінг, спрямований на корекцію особистісної саморегуляції в учнів підліткового віку, має свою логіку, цільову спрямованість, теоретичну основу і зорієнтований на зміни визначених властивостей і якостей особистості.

Необхідно зазначити, що для успішної реалізації програми психологічного тренінгу корекції механізмів саморегуляції поведінки підлітків потрібно застосовувати різні психологічні підходи і методи, які забезпечать взаємне проникнення й доповнення під час формування навичок особистісної саморегуляції підлітків, у кінцевому підсумку приводять до того, що молода особистість удосконалює свою поведінку, набуває нових умінь і якостей, змінює систему взаємин із соціальним оточенням.

Становлення механізмів саморегуляції поведінки підлітків базується на розвитку самосприйняття, рефлексії, самовизначення, самопізнання. Основними шляхами корекційної роботи з підлітками є: переорієнтація з досяг- нення результатуна спосіб виконаннязавдання, актуалізація потреби досягнення успіху, усвідомлення пріоритету просоціальних цінностей у життєвому просторі, проєктування рефлексивних очікувань референтних осіб, активізація інтернального локусу контролю тощо.

Проведене дослідження не вичерпує всіх аспектів проблеми. Перспективу ії дослідження вбачаємо у виявленні специфічного змісту і значущості рефлексії, оцінних очікувань, самоконтролю, самовизначення й особистісної позиції в контексті саморегуляції поведінки підлітків.

\section{ЛІТЕРАТУРА:}

1. Бандура А. Теория социального научения. Санкт-Петербург : Евразия, 2003. 320 с.

2. Боришевський М.Й. Моральна саморегуляція поведінки особистості : понятійний апарат. Київ : ІІн-т психології ім. Г.С. Костюка, 1993. 24 с.

3. Выготский Л.С. Орудие и знак в развитии ребенка. Собрание сочинений : в 6-и т. / Л.С. Выготский. Москва : Просвещение, 1984. Т. 6 : Научное наследство / под. ред. А.М. Матюшкина. С. 5-91.

4. Кузікова С.Б. Теорія і практика вікової психотерапії : навчальний посібник для студентів вищих педагогічних закладів. Суми : Університетська книга, 2006. 383 c.

5. Лефтеров В.О. Особистість і тренінг: транссрормація психічного. Наука і освіта. 2007. № 6/7. C. $19-23$.

6. Маслоу А. Мотивация и личность. СанктПетербург : Питер, 2014. 369 c.

7. Миславский Ю.А. Саморегуляция и активность личности в юношеском возрасте. Москва : Педагогика, 1991. 151 с.

8. Роджерс Карл Р. Становление личности. Взгляд на психотерапию. Санкт-Петербург : ЭксмоПресс, 2001. 465 c.

9. Сінєльнікова Т.В. Психологічний тренінг та його теоретико-методологічні основи. Наука і освіта. 2004. № 4/5. С. 66-69.

10. Фрейджер P., Фейдимен Д. Личность : теории, эксперименты, упражнения. Санкт-Петербург : Прайм-Еврознак, 2004. 608 с. 